\title{
Genetic predisposition to breast and ovarian cancer
}

\author{
Pierre O. Chappuis ${ }^{\mathrm{a}}$, Barbara Bolliger ${ }^{\mathrm{b}^{*}}$, Nicole Bürki ${ }^{\mathrm{i}^{*}}$, Katharina Buser $^{\mathrm{d} *}$, Karl Heinimann ${ }^{\mathrm{e}^{*}}$, Christian Monnerat $^{\mathrm{f}^{*}}$, \\ Rudolf Morant ${ }^{{ }^{*}}$, Olivia Pagani ${ }^{{ }^{*}}$, Lucien Perey ${ }^{\mathrm{i}^{*}}$, Manuela Rabaglio $\mathrm{i}^{\mathrm{i}^{*}}$, Sheila Unger ${ }^{\mathrm{k}^{*}}$, on behalf of the Swiss \\ Group for Clinical Cancer Research (SAKK) Network for Cancer Predisposition Testing and Counseling \\ a Division of Oncology and Division of Genetic Medicine, University Hospitals of Geneva, CH-1205 Geneva; ${ }^{b}$ Tumor- und Brustzentrum ZeTuP, \\ CH-9006 St. Gallen; ${ }^{c}$ Division of Gynecologic Oncology, University Hospital Basel, CH-4055 Basel; ' ${ }^{d}$ Sonnenhof Klinik Engeried, CH-3012 Bern; \\ e Division of Medical Genetics, University Hospital Basel, CH-4031 Basel; ${ }^{\dagger}$ Division of Oncology, Hôpital du Jura-Delémont, CH-2800 Delémont; \\ g Tumorzentrum ZeTuP, Rapperswil-Jona, CH-8640 Rapperswil; ${ }^{h}$ Istituto Oncologico della Svizzera Italiana, Ospedale Regionale Bellinzona e Valli, \\ CH-6500 Bellinzona; ' Division of Oncology, Hôpital de Morges, CH-1110 Morges; ' Division of Medical Oncology, UCl University Cancer Center Inselspital, \\ $\mathrm{CH}-3010$ Bern; ${ }^{k}$ Division of Medical Genetics, CHUV-Lausanne University Hospital, $\mathrm{CH}-1011$ Lausanne \\ *these authors contributed equally to this publication
}

These guidelines have been approved by the SAKK Breast Cancer Project Group and the Gynecological Cancers Working Group. This document reflects clinical and scientific advances as of the date of publication and is subject to change.

\section{Résumé}

Ces recommandations ont été élaborées à l'attention des médecins praticiens afin de mieux définir les personnes concernées par une démarche clinique particulière dans le contexte $d^{\prime}$ antécédents médicaux personnels ou familiaux évocateurs de prédispositions génétiques au cancer du sein et de I'ovaire. Cette démarche comprend une évaluation oncogénétique, soit un conseil génétique dédié pouvant aboutir à la proposition d'analyses moléculaires. Ces dernières visent à identifier des variants pathogéniques constitutionnels dans des gènes responsables d'un risque notablement accru de développer des cancers du sein et de l'ovaire par rapport à la population générale. Des mesures particulières de surveillance et de prévention dont l'efficacité est démontrée sont alors disponibles pour les personnes portant de telles prédispositions génétiques.

Ces recommandations concernent également les représentants de l'assurance obligatoire des soins selon la loi fédérale sur l'assurance-maladie (LAMal) pour la prise en charge des coûts de ces analyses moléculaires conformément à la législation en vigueur.

Par ailleurs, ces directives sont très similaires à celles déjà émises dans d'autres pays ou par d'autres sociétés savantes internationales.

Le domaine des analyses génétiques, en particulier en oncologie prédictive, est en constant développement. Ces recommandations reflètent l'état des connaissances en juillet 2016. Elles seront périodiquement réévaluées et librement accessibles sur le site Internet du Groupe Suisse de Recherche Clinique sur le Cancer (http://sakk.ch/en/sakk-provides/for-patients/geneticcounseling/).

\section{Introduction}

$B R C A 1$ and $B R C A 2$ are the main genes involved in the hereditary breast and ovarian cancer syndrome with an autosomal dominant mode of inheritance. The frequency of germ-line BRCA1/BRCA2 pathogenic variants is about 1:400 to 1:800 among healthy women from the Western non-Jewish white population. Carrying a germline mutation in BRCA1 or BRCA2 is associated with $40 \%$ to $75 \%$ cumulative risk of developing breast cancer and $15 \%$ to $60 \%$ cumulative risk for ovarian cancer by age 70 years [1]. About $3-5 \%$ of all breast cancer and $10-15 \%$ of unselected invasive ovarian cancer cases are BRCArelated [2]. Other rare high- to moderate-risk inherited syndromes can associate breast or ovarian cancer [3, 4]. The rapid translation of next-generation or massively parallel sequencing technology in diagnostic laboratory has opened impressive perspectives by allowing to test for multiple genes in a single assay (gene panel or exome) with substantial reductions both in costs and turn-around time. Some important issues have also been raised by this technological revolution, e.g. clinical validity or clinical utility of several genetic results, or identification of multiple variants of uncertain clinical significance $[5,6]$.

In Switzerland, testing for genetic predisposition to hereditary breast/ovarian cancer, particularly BRCA1/ $B R C A 2$, is available in a clinical setting. Cancer risk assessment and genetic counselling are mandatory before and after genetic testing (i.e. pre- and post-test 
Swiss guidelines for referral individuals for risk assessment, genetic counselling and testing for breast/ovarian cancer

\section{predisposition syndrome}

I. Individuals with a close relative ${ }^{1}$ with a known pathogenic variant in $B R C A 1$ or $B R C A 2$, or in another gene conferring high risk for breast and ovarian cancer.

II. WOMEN with a personal history of BREAST CANCER and one of the following:

- Age at diagnosis $<40$ years;

- Triple negative (oestrogen receptor, progesterone receptor and HER2 negative) breast cancer $\leq 60$ years;

- Age at diagnosis $\leq 50$ years, with $\geq 2$ close relatives ${ }^{1}$ with breast cancer at any age or with only 1 close relative ${ }^{1}$ with breast cancer $\leq 50$ years;

- Bilateral breast cancer, if the first cancer was diagnosed $\leq 50$ years;

- Bilateral breast cancer at any age, with $\geq 1$ close relative ${ }^{1}$ with breast cancer [if only one relative affected, then age at diagnosis $\leq 50$ years];

- Diagnosed at any age, with $\geq 1$ close relative ${ }^{1}$ with ovarian ${ }^{2}$ cancer at any age;

- Diagnosed at any age, with $\geq 2$ close relatives ${ }^{1}$ with breast cancer [particularly if $\geq 1$ breast cancer diagnosed $\leq 50$ years or if bilateral breast cancer];

- A close male relative ${ }^{1}$ with breast cancer (any age);

- A personal history of ovarian ${ }^{2}$ cancer;

III. Women with a personal history of OVARIAN ${ }^{2}$ CANCER and one of the following:

- Non-mucinous epithelial subtypes, particularly high grade serous histology, at any age;

- A personal history of breast cancer;

- One or more close relatives ${ }^{1}$ with ovarian ${ }^{2}$ cancer (any age);

- One or more close female or male relatives ${ }^{1}$ with breast cancer, particularly if breast cancer diagnosed $\leq 50$ years;

IV. MEN with a personal history of BREAST CANCER:

- Particularly, if one or more close male relatives ${ }^{1}$ with breast cancer;

- Particularly, if one or more close female relatives ${ }^{1}$ with breast or ovarian ${ }^{2}$ cancer;

\section{Ashkenazi Jewish heritage:}

Search for the 3 founder BRCA1 and BRCA2 pathogenic variants ${ }^{3}$ regardless of personal or family history;

\section{Family history only (i.e. unaffected individuals):}

One or more close relatives ${ }^{1}$ with breast or ovarian ${ }^{2}$ cancer fulfilling one of the above criteria (points II-IV).

1 Close relative is defined as a first- or a second-degree relative on the same side of the family:

- first-degree relatives: mother/father, sister/brother, daughter/son;

- second-degree relatives: grandparents, aunt/uncle, niece/nephew, grandchildren.

2 Ovarian cancer also includes primary peritoneal cancer and fallopian tube cancer.

3 BRCA1: c.68_69delAG, c.5266dupC; BRCA2: c.5946delT. counselling). This genetic analysis is covered by health insurances only after formal genetic counselling and informed consent according to the KVL/OPAS/OPre art. 12d, let. f [7]. Twenty-five centres throughout Switzerland are currently doing risk assessment and counselling individuals with an increased risk for hereditary breast/ovarian cancer syndromes [cf. Annex online]. Routine BRCA1 or BRCA2 testing is not recommended $[4,8]$. Only individuals with a personal history or whose maternal or paternal family history is suggestive of an increased risk of pathogenic variants in highrisk cancer predisposition genes should be referred for counselling and considered for genetic testing, if they agree with this procedure. Targeted medical interventions such as intensive screening, prophylactic surgery, or chemoprevention can be recommended according to the individual risk situation, and particularly to unaffected family members identified as carriers of pathogenic genetic variants $[2,4,8,9]$.

\section{Swiss guidelines for genetic counselling and testing for breast and ovarian cancer predisposition}

The present paper summarises the Swiss guidelines for genetic counselling and ultimately testing individuals with an increased probability for carrying mutations in high-risk breast/ovarian cancer predisposition genes, particularly BRCA1/BRCA2. Risk assessment is mainly based on some particular personal and/or family history patterns on both side of the family, including:

- early-age onset of breast cancer;

- number of breast cancer cases across generations;

- bilateral breast cancer;

- ovarian cancer: of note, peritoneal and fallopian tube cancers should be considered as part of the spectrum of the hereditary breast/ovarian cancer syndrome;

- ethnic origin: currently limited to Ashkenazi Jews in our population.

Adapted from recently published guidelines $[3,4,8,10]$, it is reasonable to refer individuals with the following personal and/or family history for genetic counselling and testing for high-risk predisposition genes, particularly BRCA1/BRCA2 (see box on the left).

\section{Comments}

1) Meeting one or more of these criteria warrants further personalised genetic risk assessment and genetic counselling which will cover explanation of inheritance pattern, available testing options, discussion of disease management, treatment, surveillance and prevention options. 
2) Consider referral of cases with a weaker history of breast cancer if there is a family history of pancreatic cancer or prostate cancer, particularly at an early age at diagnosis ( $\leq 60$ years), or sarcoma $<45$ years, or glioma, or childhood adrenal cortical carcinoma, or complicated patterns of multiple cancers at a young age.

3) Particular clinical situations not included in one of the above criteria should be discussed individually, e.g. ductal carcinoma in situ (DCIS) at an early age of onset ( $<40$ years), small or uninformative families or adoption.

4) Borderline ovarian tumour is not considered as part of the spectrum of the hereditary breast/ovarian cancer syndrome.

5) Among the Ashkenazi Jewish population, the 3 BRCA1 and BRCA2 founder pathogenic variants (BRCA1: c.68_69delAG, c.5266dupC; BRCA2: c.5946delT) account for $98-99 \%$ of mutations identified and are carried by about $2.6 \%(1 / 40)$ of this population.

Address and contact information of the Swiss centres that offer genetic counseling and evaluation for cancer predisposition gene testing according to the Swiss regulation of the Krankenpflege Leistungsverordnung $(\mathrm{KVL}) /$ Ordonnance sur les prestations de l'assurance des soins (OPAS)/Ordinanza sulle prestazioni (OPre) are published online: bullmed.ch $\rightarrow$ Numéro actuel $\rightarrow$ ou Archives $\rightarrow$ Numéro 18 . Regular update on http:// sakk.ch/en/sak-provides/ for-patients/geneticcounseling

Correspondence:

PD Dr. med. Pierre

O. Chappuis

Unit of oncogenetics and cancer prevention Division of Oncology University Hospitals of Geneva (HUG)

Bd. de la Cluse 30 CH-1205 Geneva Phone: 0223729853 Fax: 0223723363 pierre.chappuis[at]hcuge.ch
6) When an appropriate affected family member is unavailable, testing of a family relative without a cancer diagnosis should be considered.

7) Genetic testing for adult-onset diseases, such as $B R C A 1 / B R C A 2$-related disorders, is not recommended in children $<18$ years.

8) Genetic testing on formalin-fixed and paraffin-embedded tumoral tissue is yet feasible to identify mutations predictive of response to treatment, e.g. identification of somatic or potentially germ-line $B R C A 1$ or $B R C A 2$ pathogenic variants and decision to introduce platinum-based drugs or poly(ADP-ribose) polymerase inhibitors. Currently, this molecular approach does not replace the search for germline pathogenic variants based on a blood sample in the context of a suspicion of genetic predisposition to hereditary breast/ovarian cancer.

\section{Conclusion}

Cancer genetic predisposition is a complex clinical and socio-psychological condition which requires harmonisation in medical practice and close interdisciplinary collaboration. An adequate identification of individuals who can potentially benefit from genetic counselling and testing is the essential prerequisite for a positive risk/benefit ratio. Health care professionals should therefore be aware of the personal and/or family history patterns that are associated with an increased risk for germ-line pathogenic variants to allow for the most effective management of hereditary breast and ovarian cancer families and the most efficient utilisation of health care resources.

\section{Acknowledgements}

We thank all the members of the SAKK Section Network for Cancer Predisposition Testing and Counseling and other colleagues for their fruitful comments.

\section{Disclosure statement}

No financial support and no other potential conflict of interest relevant to this article was reported.

\section{References}

1 Mavaddat N, Peock S, Frost D, Ellis S, Platte R, Fineberg E, et al., EMBRACE. Cancer risks for BRCA1 and BRCA2 mutation carriers: results from prospective analysis of EMBRACE. J Natl Cancer Inst. 2013;105(11):812-22.

2 Tung N. Management of women with BRCA mutations. JAMA. 2011;305(21):2211-20

3 The American College of Obstetricians and Gynecologists (ACOG). Committee Opinion. Number 634. June 2015. Available from: www.acog.org.

4 National Comprehensive Cancer Network (NCCN) Clinical Practice Guidelines in Oncology. Genetic/familial high-risk assessment: breast and ovarian [v.2. 2016; March 15, 2016]. Available from: www.nccn.org.

5 Easton DF, Pharoah PD, Antoniou AC, Tischkowitz M, Tavtigian SV, Nathanson KL, et al. Gene-panel sequencing and the prediction of breast-cancer risk. N Engl J Med. 2015;372(23):2243-57.

6 Thompson ER, Rowley SM, Li N, McInerny S, Devereux L, WongBrown MW, et al. Panel testing for familial breast cancer: calibrating the tension between research and clinical care. J Clin Oncol. 2016;34(13):1455-9.

7 Verordnung des EDI über Leistungen in der obligatorischen Krankenpflegeversicherung. [Updated 2016 May 1.] Available from https://www.admin.ch/opc/de/classified-compilation/19950275/ index.html

8 Nelson HD, Huffman LH, Fu R, Harris EL. Genetic risk assessment and BRCA mutation testing for breast and ovarian cancer susceptibility: systemic evidence review for the U.S. Preventive Services Task Force. Ann Intern Med. 2005;143(5):362-79.

9 Robson ME, Storm CD, Weitzel J, Wollins DS, Offit K. American Society of Clinical Oncology policy statement update: genetic and genomic testing for cancer susceptibility. J Clin Oncol. 2010;28(5):893-901.

10 National Institute for Health and Clinical Excellence (NICE). Familial breast cancer: classification, care and managing breast cancer and related risks in people with a family history of breast cancer. Clinical guideline (CG164) 2013. Available from: www.nice.org.uk

11 Robson M, Offit K. Management of an inherited predisposition to breast cancer. N Engl J Med. 2007;357(2):154-62.

12 Paluch-Shimon S, Cardoso F, Sessa C, Balmana J, Cardoso MJ, Gilbert F, et al. Prevention and screening in BRCA mutation carriers and other breast/ovarian hereditary cancer syndromes: ESMO Clinical Practice Guidelines for cancer prevention and screening. Ann Oncol. 2016;(suppl 5):v103-10. 